\title{
Peace Journalism in Framing Radical Islamic Issues in Bali
}

\author{
Ni Made Ras Amanda Gelgel \\ Udayana University Bali, Indonesia \\ rasamanda13@unud.ac.id
}

\section{Abstract}

Nowadays, radical Islamic issues has becoming an international's issues. News stories in media filled by this issue. Even local media also put this issue in their agenda, like local media in Bali Province. Since Bali bombing in 2002, people in Bali have their own trauma related to radical Islamic especially terrorism. Media have the power to shape people's agenda, and to shape people's perspective in any issues. So, local media in Bali have power to influence how people in Bali to see and understand the issue. The research's quetions is how the media in Bali framing radical Islamic issues in 2018? Unit analysis in this research are Bali Post and Tribun Bali. Both of them have the highest traffic and the oldest newspaper in Bali. Research is using Entman's Framing Method, which focus in how media selected issues and what aspect is highlighted by the media during 2018. The result is peace journalism has been practiced in framing radical issues in Bali.

Keywords: Bali, Framing, Mass Media, Peace Journalism, Radical Islam.

\section{Abstrak}

JURNALISME DAMAI DALAM MEMBINGKAI ISU ISLAM RADIKAL DI $B A L I$.Saat ini, isu Islam radikal telah menjadi isu internasional. Berita di media diisi dengan isu ini. Bahkan, media lokal pun memasukkan 
isu ini ke dalam agenda mereka, seperti media lokal di Provinsi Bali. Sejak bom Bali 2002, masyarakat Bali memiliki trauma tersendiri terkait dengan Islam radikal khususnya terorisme. Media memiliki kekuatan untuk membentuk agenda orang dan untuk membentuk perspektif orang dalam masalah apapun. Jadi, media lokal di Bali memiliki kekuatan untuk mempengaruhi bagaimana masyarakat di Bali melihat dan memahami persoalan tersebut. Pertanyaan dari penelitian ini adalah bagaimana media di Bali membingkai isu Islam radikal di tahun 2018? Unit analisis dalam penelitian ini adalah Bali Post dan Tribun Bali. Keduanya memiliki traffic tertinggi dan koran tertua di Bali. Penelitian menggunakan Framing Method Entman yang menitikberatkan pada bagaimana media memilih isu dan aspek apa yang menjadi sorotan media selama tahun 2018. Hasilnya jurnalisme damai telah dipraktikkan dalam membingkai isu-isu radikal di Bali.

Kata Kunci: Bali, Framing, Media Massa, Jurnalisme Damai, Islam Radikal.

\section{A. Introduction}

Terrorism have been an international's issues. Global Media see this issue as a magnificent problem. Unfortunately, international media coverage in terrorism dominated by a pattern of Muslims / Arabs/Islam who working together in an organized terrorist. Radicalism in history of Islam itself is not a new phenomenon. ${ }^{1}$ After the terrorist attack on September 11, 2001, there was a sustained climate of fear of terrorism that is linked to Muslims. ${ }^{2}$

Media and terrorism have symbiotic relationship, terrorism capable of writing drama to compel the media's attention which can neither ignore nor deny. ${ }^{3}$ Media has an extensive impact. After 9/11, studied show 9 in 10 worried about terrorist events happening and about being a victim of a future attack. ${ }^{4}$ Maximum impact of an act

${ }^{1}$ Anzar Abdullah, "Gerakan Radikalisme dalam Islam: Perspektif Historis", ADDIN 10, no. 1 (2016), 1.

${ }^{2}$ Kimberly A. Powell, "Framing Islam: an Analysis of U.S. Media Coverage of Terrorism Since 9/11", Communication Studies 62, no. 1 (2011), 90-112.

${ }^{3}$ Abraham H. Miller, Terrorism, the Media, and the Law (New York, NY: Transnational Publishers, 1982), 1.

${ }^{4}$ B.L. Nacos, Mass-Mediated Terrorism: the Central Role of the Media in Terrorism and Counter-Terrorism (New York, NY: Rowman and Littlefield, 2007), 45. 
of terrorism comes from widespread media coverage, that creates a climate of fear among the population. ${ }^{5}$

Rasha A. Abdulla (2007) in his paper "Islam, Jihad, and Terrorism in Post 9/11 Arabic Discussion Boards" examined three of the most popular Arabic-language online messages boards regarding the attacked of September 11, 2001 on the U.S. Although terrorist claimed that the attacks were committed in the name of Islam, those who posted messages on all three forum reject the claim. Those participants viewed the attacks as a political, rather than a religious issue. It showed the opposite what mainstream media coverage. After the attacks, Islam and Muslim started to come to the forefront of the Western Media, but not for very positive reasons. A debate started brewing in the Western media over the true nature of Islam and whether or not it justified or even encouraged violence, particularly against non-Muslims. Before the attack, Abdulla (2007) shared that in 1980, journalist Djelloul Marbrouk revealed that the Arab in American Television stands for "terrorism, hijack, intractability, sullenous, cruelty, oil, sand, embargo, boycott, greed, bungling, comedic disunity, primitive torture, family feuds, and white slavery". ${ }^{6}$

Mass media knowed as distributor of ideology that created dan distributed through framing and presenting stories. Journalism as part of mass media, have a significant role to distribute ideology. News stories or Journalist have a power to be part in making peace. Hanitzsch, Thomas (2004) stressed out that there are no doubt that journalism can contribute to the peaceful settlement of conflicts ${ }^{7}$. He came up with cases after conflict in Ambon Indonesia, where there are two newspaper Suara Maluku and Ambon Ekspress. Conflict between Muslim and Christians turned Ambon into a battlefield in January 1999. Suara Maluku dominated by Christians Journalist and Ambon Ekspress dominated by Muslim journalist. In

${ }^{5}$ Kimberly A. Powell, "Framing Islam", 92.

${ }^{6}$ Rasha A. Abdulla, "Islam, Jihad, and Terrorism in Post 9/11 Arabic Discussion Board", Journal of Computer-Mediated Communication 12, no. 1 (2007), 1063-1065.

${ }^{7}$ Thomas Hanitzsch. "Journalists as Peacekeeping Force? Peace Journalism and Mass Communication Theory”, Journalism Studies 5, no. 4 (2004), 483-495. 
a second, journalist became combatants, and their media became inflammatory pamphlets.

In covering terrorist, journalism faced a different obstacle. In the terrorist attacked of September 11, 2001 in United States, had accelerated a trend of journalist to be more attachment and emotion now becoming fully embraced into the culture of journalism. Hennessy, radio journalist said his positions primarily "I am an American First, a journalist second". Journalist who experienced by themselves can be changing a paradigmatic perspective. Tumber and Prentoulis (2003) said that there is a paradigmatic shift in journalism: from detachment to involvement, from verification to assertion, from objectivity to subjectivity. Asian newspaper tends to cover conflict in war journalism frame. ${ }^{8}$ Lee and Maslog $(2005)^{9}$ researched 1,338 stories from 10 newspaper in India, Pakistan, Sri Langka, Indonesia and Philippines. The news coverage of these conflicts is dominated by a war journalism frame, where there were dominancing language, partisan approach and single party orientation.

In Indonesia, media coverage terrorism in differ stories. Soekarno (2011) stated religion radical movement being used in media in Indonesia before 1998 to replace term of terrorism. ${ }^{10}$ Even in 1999, Media still using the term Security Rebellion Movement (Gerakan Pengacau Keamanan, GPK). Term terrorism being used since 9/11 and Bali Bombing in 2001 until now.

In covering stories, Indonesia newspaper using different perspectives. In terrorist attack, they used to make a hard news that revealed law inforcement process, and condemning the act. Krissa (2016) ${ }^{11}$ showed that different media using different angle in framing terrorist attacked in Thamrin Street, Jakarta. Kompas

${ }^{8}$ Howard Tumber and Jerry Palmer, Media at War: the Iraq Crisis (Thousand Oaks, CA: Sage, 2004), 228.

${ }^{9}$ Seow Ting Lee and Crispin C. Maslog, "War or Peace Journalism? Asian Newspaper Coverage of Conflicts", Journal of Communication 55, no. 2 (2005), 311-329.

${ }^{10}$ Adam W. Sukarno, "Dilema Peliputan Terorisme dan Pergeseran Pola Framing Berita Terorisme di Media Massa", Jurnal Ilmu Sosial dan Ilmu Politik 14, no. 3 (2011).

${ }^{11}$ Kathleen Krissa, "Pembingkaian Peristiwa Teror di Jalan Mh. Thamrin Jakarta pada Harian Kompas, Media Indonesia, Republika, dan Koran Sindo: Sebuah Analisis Framing", Bachelor Thesis, Universitas Multimedia Nusantara, 2016. 
stressed in the important of public awareness by using non provocative words. Kompas asked their reader to work together against terrorism. Media Indonesia's stories stressed in political aspects. Republika's stories stressed in economic aspect. Koran Sindo's stories saw the attack in religious perspective, and related Muslim and Islam with the act.

In May 13, 2018, there were several suicide bombings in churches in Surabaya, Jawa Timur. Again, Muslim/Islam being accused as the actor of the bombing. Videos of the action can be accessed through television's news stories and through massive social media distributed. In the video, it can be seen the attacker were family and using a hijab. Therefor media accusing Islamic Radical movement behind the attacked. It became a national's issues. It also became an issue in every local media in Indonesia. How media frame the stories is different depends on regulation and ideology. Reese stated some factors that impact how stories came out to public. Stories goes to Bali, one of the homogenic province in Indonesia. 90 percent of Balinese people are Hindu. Bali also have a dark relationship with terrorism. Two terrorists acted in Bali, in 2002 dan 2005. More than 200 people die, and the bombing destroyed Bali's tourism, making thousands of people lost their job. But sociologically, the bombing drive fear among Balinese people to the Muslim and Islam itself. Mass media in Bali dominated by local media with Balinese journalist. Two biggest media in Bali is Bali Post and beritabali.com. Both of this media made news about Surabaya's bombing. As the biggest media in Bali, how they frame the stories will impact how the readers saw the tragedy in Surabaya. BaliPost.com is one of the members of the oldest media group in Bali, Kelompok Media Bali Post. People in Bali still believed that Bali Post Group is one of the media they can trust. The other media, beritabali.com is one of the media that have the biggest viewers in Bali. This paper examined how the two media in Bali frame the Surabaya bombing? Concept used in this paper is peace journalism and framing theory. 


\section{B. Discussion}

\section{Peace Journalism}

Peace Journalism introduced by Johan Galtung, and promoted by war journalist Annabel McGoldrick and Jake Lynch. Galtung identified peace journalism as a special mode of social's responsible journalism. Hanitzsch (2004) define peace journalism as a programme or frame of journalistic news coverage which contributes to the process of making and keeping peace respectively to the peaceful settlement of conflicts. ${ }^{12}$ Galtung (1998) viewed peace journalism dan war journalism as two competing frames in the coverage of a conflict, based on four broad practice. In a war, the first victim is peace. Galtung comparing concept of peace/conflict journalism and war/violence journalism with four operational content.

Table $1^{13}$

Peace/Conflict Journalism and War/Violence Journalism

\begin{tabular}{|c|c|}
\hline Peace/Conflict Journalism & War/Violence Journalism \\
\hline $\begin{array}{l}\text { 1. Peace/Conflict Oriented. } \\
\text { a. Explore conflict formation. } \\
\text { b. Open space, open time; causes } \\
\text { and outcomes. } \\
\text { c. Making conflicts transparent. } \\
\text { d. Emphaty, understanding. } \\
\text { e. Giving voice to all parties. } \\
\text { f. Focus in conflict creativity. } \\
\text { g. Humanization of all sides. } \\
\text { h. Proactive, prevention before any } \\
\text { violence/war occurs. } \\
\text { i. Focus on invisible effects of } \\
\text { violence (trauma and glory, } \\
\text { damage to structure/culture). }\end{array}$ & $\begin{array}{l}\text { 1. War/Violence Oriented. } \\
\text { a. Focus on conflict arena, war } \\
\text { general zero-sum orientation. } \\
\text { b. Closed space, close time: who } \\
\text { threw the first stone. } \\
\text { c. Making wars opaque/secret. } \\
\text { d. "Us-them" journalism, } \\
\text { propaganda. } \\
\text { e. Dehumanization of "them". } \\
\text { f. Reactive, waiting for violence } \\
\text { before reporting. } \\
\text { g. Focus only on visible effect of } \\
\text { violence (killed, wounded). }\end{array}$ \\
\hline $\begin{array}{l}\text { 2. Truth Oriented. } \\
\text { a. Expose untruth on all sides. } \\
\text { b. Uncover all cover-ups. }\end{array}$ & $\begin{array}{l}\text { 2. Propaganda Oriented. } \\
\text { a. Expose "their" untruths. } \\
\text { b. Help "our"cover-up/lies. }\end{array}$ \\
\hline
\end{tabular}

${ }^{12}$ Thomas Hanitzsch, "Journalists as Peacekeeping Force? Peace Journalism and Mass Communication Theory”, Journalism Studies 5, no. 4 (2004), 483-495.

${ }^{13}$ Johan Galtung, “Peace Journalism”, Media Asia 30, no. 3 (2003), 177-180. 


\begin{tabular}{|c|c|}
\hline $\begin{array}{l}\text { 3. People Oriented. } \\
\text { a. Focus on suffering all over, giving } \\
\text { voice to the voiceless. } \\
\text { b. Focus on people peacemakers. }\end{array}$ & $\begin{array}{l}\text { 3. Elite Oriented. } \\
\text { a. Focus on "our" suffering. } \\
\text { b. Give name of their evil-doer. } \\
\text { c. Focus on elite peacemakers. }\end{array}$ \\
\hline $\begin{array}{l}\text { 4. Solution Oriented. } \\
\text { a. Peace = non-violence + creativity. } \\
\text { b. Highlight peace initiatives, also to } \\
\text { prevent more war. } \\
\text { c. Focus on structure, culture, the } \\
\text { peaceful society. } \\
\text { d. Aftermath: resolution, re- } \\
\text { construction, reconciliation. }\end{array}$ & $\begin{array}{l}\text { 4. Victory Oriented. } \\
\text { a. Peace = victory + ceasefire. } \\
\text { b. Conceal peace-initiative. } \\
\text { c. Focus on treaty, institution the } \\
\text { controlled society. } \\
\text { d. Leaving for another war. }\end{array}$ \\
\hline
\end{tabular}

\section{Agenda-Setting and Framing Theory}

Peace journalism supported by framing theory. Broadly, news framing theory refers to the process of organizing a news story, thematically, stylistically, and factually to convey a specific story line. Entman (1993) said to frame is to select some aspects of a perceived reality and make them more salient in communicating text, in such a way as to promote a particular problem definition, causal interpretation, moral evaluation, and/or treatment recommendation for the item described. Frames package key ideas, stock phrases, and stereotypical images to bolster a particular interpretation. Through repetition, placement, and reinforcement, the texts and images provide a dominant interpretation more readily perceivable, acceptable, and memorable than other interpretations. ${ }^{14}$ Tankard (1991) explained media framing as the central organizing idea for news content that supplies a context and suggests what the issue is through the use of selection, emphasis, exclusion and elaboration. ${ }^{15}$

Framing is how the stories are made, which information are selected and how they organize the stories to their readers and

${ }^{14}$ Robert Entman, "Framing: toward Clarification of a Fractured Paradigm", Journal of Communication 43, no. 4 (1993), 52.

${ }^{15}$ J. Tankard, L. Hendrickson, J. Silberman, K. Bliss, and S. Ghanem, "Media Frames: Approaches to Conceptualization and Measurement", Paper Presented at the Annual Conference of the Association for Education in Journalism and Mass Communication Boston, MA, 1991. 
audiences. As we know every story can have different angles. This angle will create the frame. Campbell (1995) explained that journalist's perceptions and biases affected how they present information in news stories. ${ }^{16}$ Ideology, social norms ad values also affected media framing. ${ }^{17}$ It can frame what the audiences think and see, it is agenda-setting theory.

For example, Kimberly Powell explained in US, majority of news coverage through photos and words reinforce negative images of Muslim therefore the audiences are likely to conclude Muslim are terrorists ${ }^{18}$. Framing in McCombs, Shaw and Weaver (1997) perspective is an extension of agenda setting. Framing has been explicated as second-level agenda setting. The first level of agenda-setting process is transmitted object salience. The second level, framing or indicator salience, that illustrates how media tell us how to think about something. ${ }^{19}$

\section{Radical Islamic Issues in Bali}

Balipost.com and Beritabali.com as local media online in Bali should bring positive information for people in Bali. Surabaya's bombing stories also became a selected issue used by both media. Surabaya's bombing brought up Islamic radicalism issue. This issue became a sensitive issue in mass media. How Balipost.com and Beritabali.com frame Islamic radicalism issue will be explained below here. Galtung said in a conflict situation, media should take a part by making and keeping peace respectively to the peaceful settlement of conflicts. In this research, researcher focus in 5 article news, 3 from Beritabali.com and 2 from Balipost.com.

\footnotetext{
${ }^{16}$ C.P. Campbell, Race, Myth, and The News (CA: Sage, 1995).

${ }^{17}$ D.A. Scheufele, "Framing as a Theory of Media Effects", Journal of Communication 49, no. 1 (1999), 109.

${ }^{18}$ Kimberly A. Powell, "Framing Islam: an Analysis of U.S. Media Coverage of Terrorism Since 9/11", Communication Studies 62, no. 1 (2011), 90-112.

${ }^{19}$ M. McCombs, D.L. Shaw, and D. Weaver, Communication and Democracy: Exploring the Intellectual Frontiers in Agenda-Setting Theory (Mahwah, NJ: Erlbaum, 1997).
} 
a. "Antisipasi Teror Bom, Polda Bali Sempat Amankan Wanita Bercadar" ("Anticipating Bom Terror, Denpasar Regional Police Secure a Woman"), Beritabali.com, Monday, May 14, 2018. ${ }^{20}$

Picture 1

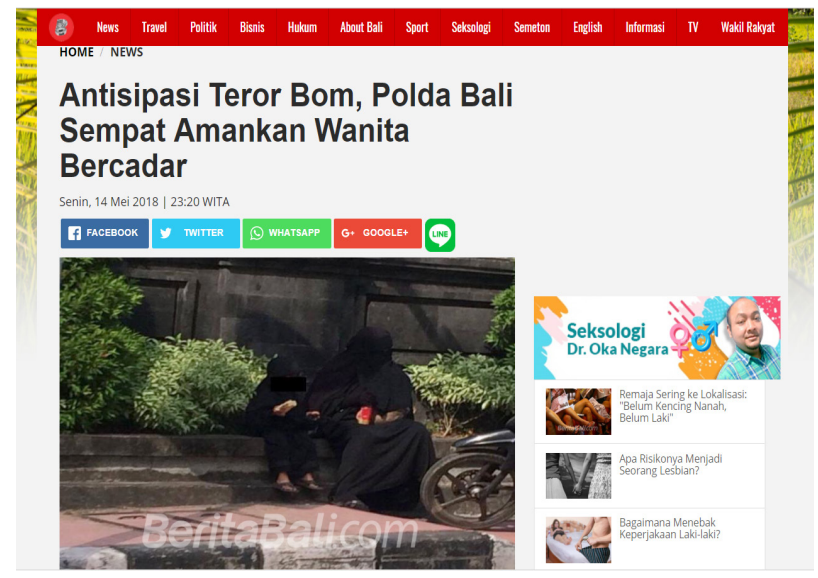

In the news published by Beritabali.com on May 14, 2018, it was mentioned that after the Surabaya bombing which targeted worship places such as churches and police offices, the Bali Regional Police has increased their awareness of various potentials, including the presence of a veiled woman accompanied by a child and rested around the police station and even entered the boarding area of the Bali Police on the Angsoka street, Ngurah Rai Sport Center Denpasar. Hearing the complaints of residents who were also reporting because they were worried about the incident, the Denpasar Regional Police immediately took a stand by interrogating and searching the woman. However, the interrogation proved that the veiled woman did not have objects or other dangerous materials.

20"Antisipasi Teror Bom, Polda Bali Sempat Amankan Wanita Bercadar", Beritabali. com, May 14, 2018, https://www.beritabali.com/read/2018/05/14/201805140020/ Antisipasi-Teror-Bom-Polda-Bali-Sempat Amankan-Wanita-Bercadar.html, accessed August $13,2019$. 
In the news mentioned that the woman was only interrogated in accordance with the rules, and was proven innocent. Therefore, she could be released. Public Relations Head of Bali Police also said that the presence of a veiled woman around the Bali Police office is a normal activity of the community and has nothing to do with terrorism.

On the other hand, in the news with the same title published by Beritabali.com is also mentioned that there was an inspection by the Bali Regional Police on a married couple which the wife wore a veil as well. After an intensive examination by the Bali Police on suspicions related to acts of radicalism, the police found no evidence that the couple who lived in the Sidakarya area of Denpasar was involved in terrorist networks.

The steps taken by the Bali Police in following up on the alleged threats from radical elements written by Beritabali. com are indeed very responsive. This is certainly based on the unrest of the people who are traumatized by the Surabaya bombings involving actors from radical networks that are semiotic, appear to have the same common thread, that is both have radical Islamic understanding, and the female actors involved are equally wearing veil.

Beritabali.com also wrote that the Bali Regional Police had blocked the access road directly in front of the Bali Regional Police Office. Many people speculated that the closure of the road was the result of an interrogation of veiled woman who was considered troubling the residents. However, the Bali Regional Police through their representatives stressed that the road closure was solely for the purpose of diverting traffic access and had nothing to do with the incident. Here, it can be seen that Beritabali.com seeks to strip away public unrest by providing complete information and is accompanied by reliable confirmation. So it is expected to reduce the noise that occurred in the community due to the incident. 
b. "Remaja Denpasar Berharap Tak Ada Diskriminasi Karena Berpakaian Mirip Teroris" ("Denpasar Youth Hopes There Is No Discrimination for Dressing Like Terrorists"), Beritabali. com, Wednessday, May 23, 2018. ${ }^{21}$

Beritabali.com, Denpasar. Remaja di Kota Denpasar berharap tidak ada diskriminasi terhadap orang yang berpakaian mirip dengan pakaian teroris. Para remaja Denpasar juga berharap tidak ada prasangka berlebihan dan mengkaitkan dengan aksi terorisme karena cara berpakaian ataupun karena alasan agama. Harapan tersebut salah satunya disampaikan oleh remaja asal Kertalangu Denpasar, I Nyoman Tri Sendyana. Apalagi terorisme tidak dapat dinilai dari penampilan dan agama.

Picture 2

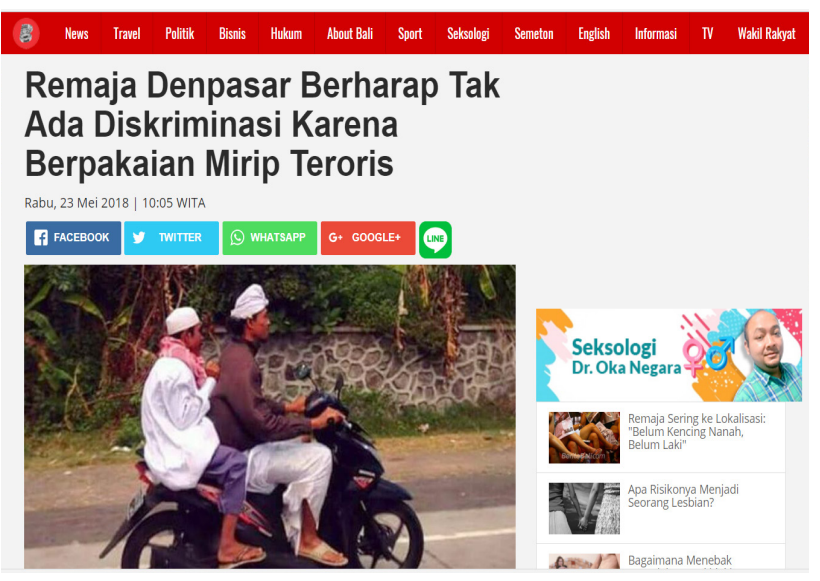

Previously, Beritabali.com had a chance to discuss suspicion of the veiled woman, where in the news, Beritabali.com tried to justify the stigma that the people in Bali were feeling traumatized and worried about some people who in terms of appearance looked suspicious. But this time, Beritabali.com raised the title

21"Remaja Denpasar Berharap Tak Ada Diskriminasi Karena Berpakaian Mirip Teroris", Beritabali.com, May 23, 2018, https://www.beritabali.com/ $\mathrm{read} / 2018 / 05 / 23 / 201805230007 /$ Remaja-Denpasar-Berharap-Tak-Ada-DiskriminasiKarena-Berpakaian-Mirip-Teroris.html, accessed August 13, 2019. 
"Denpasar Youth Hopes There Is No Discrimination for Dressing Like Terrorists". From the title chosen, Beritabali.com was again trying to quell citizen unrest by raising positive news that tends to direct the mindset of people in Bali, especially young people to be able to accept differences.

In the news released on Wednesday, May 23, 2018, Beritabali.com summarized many opinions of young people or teenagers in Denpasar. Many of these teenagers invited the public not to behave discriminatively against the teachings or ways of dressing of certain groups. It can be seen from this article, Beritabali.com wants to see the problem from the different perspective.

The choice of adolescents aged 15-18 years as respondents in this news also raised the perception that teenagers in Bali nowadays have an open mindset and are ready to face differences. In addition, this article also mentioned that many of the teenagers in Denpasar are concerned about the behavior and mindset of most Balinese who judge someone only by their appearance.

In addition to writing the opinions of teenagers, Beritabali.com also wrote the opinions of academics to balance the opinions expressed by the youth. The opinion of the academics is expected to help strengthen the perception of the young people to invite the public to judge the book by its cover, or not prioritize the physical appearance of one's own background.

c. "Kecam Aksi Terorisme, MUDP Bali Minta Desa Pekraman Tingkatkan Kewaspadaan" ("Condemn All Forms of Terrorism, Main Assembly of Bali's Pekraman Village Ask Pekraman Village to Increase Awareness"), Beritabali.com, Friday, May $18,2018 .^{22}$

22“Kecam Aksi Terorisme, MUDP Bali Minta Desa Pekraman Tingkatkan Kewaspadaan", Beritabali.com, May 18, 2018, https://www.news.beritabali.com/ read/2018/05/18/201805180009/kecam-aksi-terorisme-mudp-bali-minta-desapekraman-tingkatkan-kewaspadaan, accessed August 13, 2019. 
Beritabali.com. Denpasar. Majelis Utama Desa Pakraman (MUDP) Bali menyatakan sikap mengecam dan mengutuk aksi terorisme yang terjadi di Surabaya dan daerah lain di Indonesia. Hal tersebut disebutkan Bendesa Agung MUDP Bali Jero Gede Suwena Putus Upadesha dalam pertemuan dengan jajaran MUDP Bali, Jumat (18/5) di Denpasar.

Picture 3

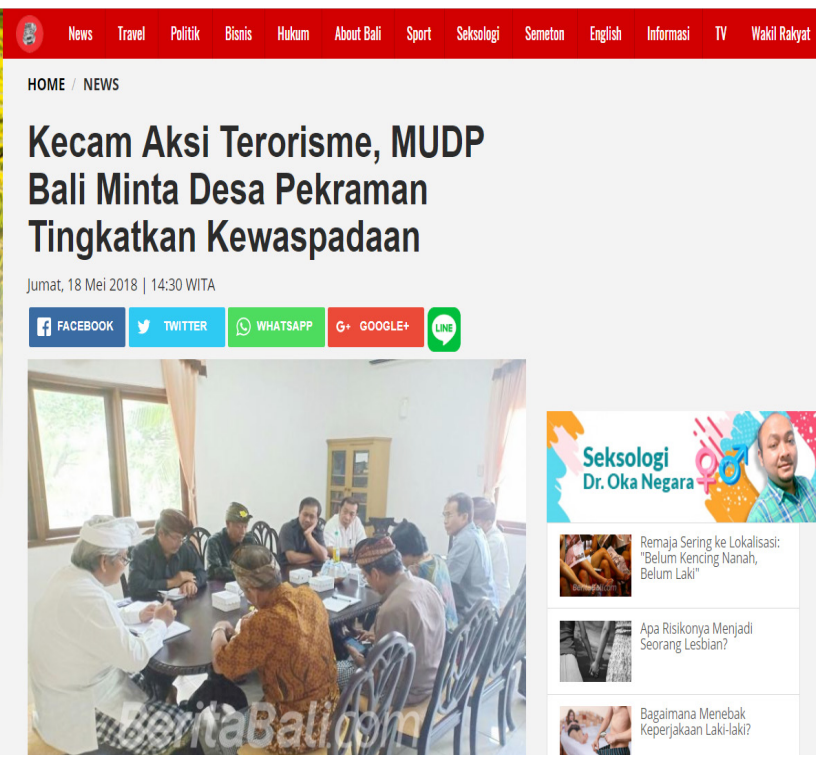

The selected news that the researchers used in this study is about the Main Assembly of Bali's Pekraman Village which stated its attitude to condemn all forms of terrorism that occurred in the territory of the Republic of Indonesia, especially acts of terrorism involving women and minors.

The meeting held by Main Assembly of Bali's Pekraman Village was reported by Beritabali.com and initiated by the anxiety of Balinese people as a result of several criminal acts committed by terrorists. A letter of agreement was also signed during the event so that all elements of the community would not be provoked and entrusted the legal process to the authorities. 
In addition, a letter signed by all Main Assembly of Bali's Pekraman Village members also contained requests for all Bali Pekraman villages to always increase awareness of the newcomers entering their respective areas. In this case, beritabali.com as the local online media of Bali tried to provide complete information to the public in order to increase public attention and knowledge on how to anticipate the dangers posed by terrorist networks through appeals issued by the Main Assembly.

In this case, Beritabali.com provided information that was very useful to reduce public unrest in Bali. In addition, the choice of raising news about the agreement from Main Assembly of Bali's Pekraman Village has a positive influence on the community and was very appropriate to share. It is undeniable that the Balinese people who are highly upholding the elements of regionalism and tradition that directly put Main Assembly of Bali's Pekraman Village as a strategic institution capable of influencing the people in Bali.

d. "Pawai Ta’aruf, Warga Kecicang Islam Kutuk RadikalismeTerorisme" ("Ta'aruf Parade, Citizens of Islamic Branches Curse the Radicalism-Terrorism"), Balipost.com, Thursday, May 17, 2018. ${ }^{23}$

Balipost.com, Amlapura. Menyambut datangnya bulan puasa, Selasa (15/5) malam warga muslim Banjar Kecicang Islam, Desa Bungaya Kangin, Kecamatan Karangasem menggelar pawai ta'aruf. Pawai yang mirip Malam Pengerupukan menjelang Hari Raya Nyepi tapi tanpa ogohogoh itu dipusatkan di sepanjang Jalan Veteran atau Bypass Jalur 11 Karangasem setelah sebelumnya start dari Masjid Jami Baiturrahim, Kecicang Islam.

23“Pawai Ta'aruf, Warga Kecicang Bali Kecam Radikalisme-Terorisme”, Balipost.com, May 17, 2018, http://www.balipost.com/news/2018/05/17/45722/Pawai-Taaruf,WargaKecicang-Islam...html, accessed August 13, 2019. 


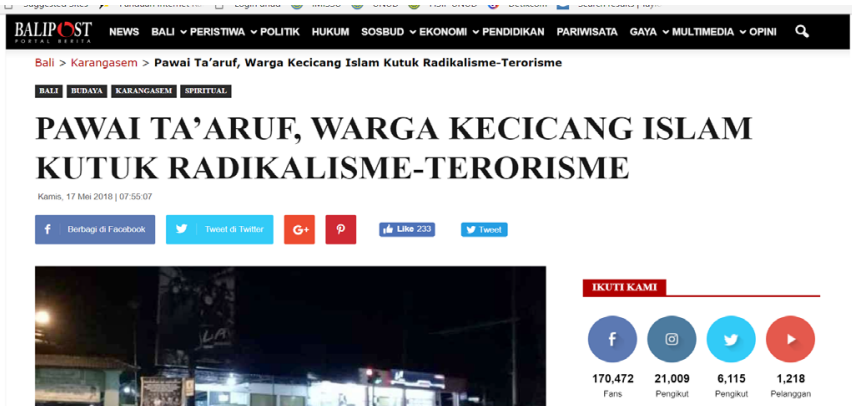

Related to the extensive reporting of terrorism cases in May, Balipost.com also contributed to disseminating information related to it. For example, the story entitled "Pawai Ta'aruf, Warga Kecicang Islam Kutuk Radikalisme-Terorisme" ("Ta'aruf Parade, Citizens of Islamic Branches Curse the Radicalism-Terrorism") which was distributed on Thursday, May 17, 2018.

In the news, Balipost.com mentioned that in order to recite the holy month of Ramadan, Moslems citizens of Banjar Kecicang Islam, Bungaya Village, East Karangasem, held a Ta'aruf parade. The parade was said to be similar to the Balinese ogoh-ogoh parade and centered on Veteran Street, Karangasem. Ta'aruf parade is a routine activity carried out by Moslems in Banjar Kecicang Islam. However, the parade this time was a little different from usual. A number of residents were seen unfurling banners in support of the police in cracking down on terrorism, fighting radicalism, and condemning terrorist acts that occurred in the city of Surabaya and several other cities in the country.

What is done by the residents of Banjar Kecicang written in Balipost.com is a form of tolerance between religious communities. Judging from the steps taken by the citizens of Kecicang, it indicates that the Kecicang residents who are Moslems also strongly condemn the behavior of terrorism carried out by a number of radical elements who uphold certain religious teachings. 
e. "Karena Ini, Radikalisme Tak Bisa Berkembang di Indonesia" ("Because of This, Radicalism Can Not Grow in Indonesia"), Balipost.com, Sunday, May 20, 2018. ${ }^{24}$

Balipost.com, Denpasar. Radikalisme bukan "barang" baru. Sudah ada dari dulu bahkan sejak zaman Soeharto. Namun radikalisme tidak mampu berkembang di Indonesia karena warga negara Indonesia memiliki jiwa nasionalisme yang tinggi. "Itu sudah dibuktikan sampai saat ini, negara kita masih kokoh berdiri. Artinya bahwa orang-orang penganut paham radikalisme tidak mampu berkembang biak karena seluruh komponen masyarakat Indonesia bergandengan tangan saling bahu membahu untuk mempertahankan NKRI," kata Dr. Gede Wirata, S.Sos., S.H., M.AP., Dekan Fakultas Ilmu Sosial dan Ilmu Politik Universitas Ngurah Rai (Fisipol UNR), Sabtu (19/5).

Picture 5

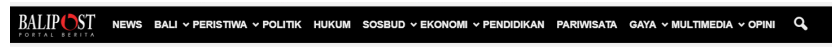

EAMI DENPASAR HIKUMI

KARENA INI, RADIKALISME TAK BISA

BERKEMBANG DI INDONESIA
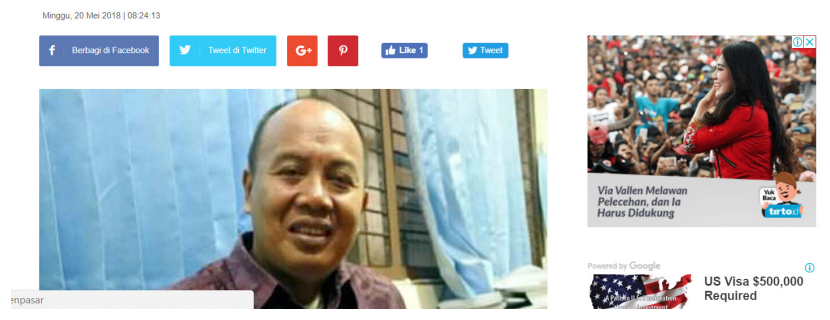

In this article, Balipost.com revealed how the Indonesian people, especially in Bali, protect themselves from the influence of radicalism. This was also supported by competent speakers in the social and political fields to discuss the issue of radicalism, Dr. Gede Wirata, S.Sos., S.H., M.AP., Dean of the Faculty of Social and Political Sciences, Ngurah Rai University.

24“Karena Ini, Radikalisme Tak Bisa Berkembang di Indonesia”, Balipost.com, May 17, 2018, http://www.balipost.com/news/2018/05/20/45920/Karena-Ini,RadikalismeTak-Bisa...html, accessed August 13, 2019. 
Balipost.com added, in addition to the majority of Indonesian people who still uphold their nationalist spirit, it is said that the Indonesian people in general and Bali in particular have customs and culture that work as well as becoming rules and norms for social life. Although it is mentioned that there are still some people who have differences of understanding which later re-surfaced (radicalism), but the levels are not in an emergency condition, because it is proven that the Republic of Indonesia is still strong until today. In addition, Balipost.com also reminded the public that radical actions caused by differences in understanding should be addressed wisely. Being vigilant and cautious is one way that can be done to anticipate unwanted things that can occur in everyday life. Therefore, in an era that has many technological advances, Balipost.com said that the media has an important role to provide a balanced portion of reporting in order not to cause excessive noise in the community.

\section{Peace Journalism in Bali}

Using Entman method, the five news above have different selected issues. The first news, came up with the issue, that people worried with a woman using hijab and veil who walk around Police stations. The second news came up with issues that young people in Denpasar hoped people should not discriminate person who wearing the same dress like executor in Surabaya's bombing. The third news came up with MUDP, Main Assembly of Bali's Pekraman Village encourage people in Bali not to react and stay calm. The fourth news came up with Islam community in Bali condemned the radical-terrorist act happened in Surabaya. The fifth news came up with radicalism cannot growth in Indonesia. 
Table 2

News Framing by Entman's Method

\begin{tabular}{|c|c|c|c|}
\hline No. & News' Title & Selected Issue & Emphasized Aspect \\
\hline 1 & $\begin{array}{l}\text { "Antisipasi Teror } \\
\text { Bom, Polda Bali } \\
\text { Sempat Amankan } \\
\text { Wanita Bercadar" } \\
\text { "Anticipating Bom } \\
\text { Terror, Denpasar } \\
\text { Regional Police } \\
\text { Secure a Woman in } \\
\text { Veil" } \\
\text { Beritabali.com, } \\
\text { Monday, May 14, } \\
2018\end{array}$ & $\begin{array}{l}\text { People worried } \\
\text { with a woman } \\
\text { using hijab and } \\
\text { veil who walk } \\
\text { around Police } \\
\text { Stations. }\end{array}$ & $\begin{array}{l}\text { - The woman was only } \\
\text { interrogated in accordance } \\
\text { with the rules, and was } \\
\text { proven innocent. } \\
\text { - The presence of a veiled } \\
\text { woman around the Bali } \\
\text { Police Office is a normal } \\
\text { activity of the community } \\
\text { and has nothing to do with } \\
\text { terrorism. } \\
\text { The purpose of diverting } \\
\text { traffic access and had } \\
\text { nothing to do with the } \\
\text { incident. }\end{array}$ \\
\hline 2 & $\begin{array}{l}\text { "Remaja Denpasar } \\
\text { Berharap Tak } \\
\text { Ada Diskriminasi } \\
\text { Karena Berpakaian } \\
\text { Mirip Teroris" } \\
\text { "Denpasar Youth } \\
\text { Hopes There Is } \\
\text { No Discrimination } \\
\text { for Dressing Like } \\
\text { Terrorists" } \\
\text { Beritabali.com, } \\
\text { Wednessday, May } \\
\text { 23, 2018 }\end{array}$ & $\begin{array}{l}\text { Young people } \\
\text { in Denpasar } \\
\text { hoped people } \\
\text { should not } \\
\text { discriminate } \\
\text { person who } \\
\text { wearing the } \\
\text { same dress } \\
\text { like executor } \\
\text { in Surabaya's } \\
\text { bombing. }\end{array}$ & $\begin{array}{l}\text { - The people in Bali were } \\
\text { feeling traumatized and } \\
\text { worried about some } \\
\text { people who in terms } \\
\text { of appearance looked } \\
\text { suspicious. } \\
\text { - Beritabali.com was again } \\
\text { trying to quell citizen } \\
\text { unrest by raising positive } \\
\text { news that tends to direct } \\
\text { the mindset of people } \\
\text { in Bali, especially young } \\
\text { people to be able to accept } \\
\text { differences. } \\
\text { Teenagers invited the } \\
\text { public not to behave } \\
\text { discriminatively against } \\
\text { the teachings or ways of } \\
\text { dressing of certain groups. } \\
\text { - Image are strongly send } \\
\text { messages that Balinese } \\
\text { and Moslems people have } \\
\text { a good relationship. }\end{array}$ \\
\hline
\end{tabular}


Peace Journalism in Framing Radical Islamic Issues in Bali

\begin{tabular}{|c|c|c|c|}
\hline 3 & $\begin{array}{l}\text { "Kecam Aksi } \\
\text { Terorisme, } \\
\text { MUDP Bali Minta } \\
\text { Desa Pekraman } \\
\text { Tingkatkan } \\
\text { Kewaspadaan" } \\
\text { "Condemn all forms } \\
\text { of Terrorism, Main } \\
\text { Assembly of Bali's } \\
\text { Pekraman Village } \\
\text { Ask Pekraman } \\
\text { Village to Increase } \\
\text { Awareness" } \\
\text { Beritabali.com, } \\
\text { Friday, May 18, } \\
2018\end{array}$ & $\begin{array}{l}\text { MUDP, Main } \\
\text { Assembly of } \\
\text { Bali's Pekraman } \\
\text { Village } \\
\text { encourage } \\
\text { people in Bali } \\
\text { not to react and } \\
\text { stay calm. }\end{array}$ & $\begin{array}{l}\text { - Surabaya's Bombing acts } \\
\text { of terrorism involving } \\
\text { women and minors. } \\
\text { - } \text { MUDP hope the } \\
\text { community would not be } \\
\text { provoked and entrusted } \\
\text { the legal process to the } \\
\text { authorities. } \\
\text { - The choice of raising news } \\
\text { about the agreement from } \\
\text { Main Assembly of Bali's } \\
\text { Pekraman Village has } \\
\text { a positive influence on } \\
\text { the community and was } \\
\text { very appropriate to share } \\
\text { and MUDP is a strategic } \\
\text { institution capable of } \\
\text { influencing the people in } \\
\text { Bali. }\end{array}$ \\
\hline 4 & $\begin{array}{l}\text { "Pawai Ta'aruf, } \\
\text { Warga Kecicang } \\
\text { Islam Kutuk } \\
\text { Radikalisme- } \\
\text { Terorisme" } \\
\text { "Ta'aruf Parade, } \\
\text { Citizens of Islamic } \\
\text { Branches Curse } \\
\text { the Radicalism- } \\
\text { Terrorism" } \\
\text { Balipost.com, } \\
\text { Thursday, May 17, } \\
\text { 2018 }\end{array}$ & $\begin{array}{l}\text { Islam } \\
\text { community in } \\
\text { Bali condemned } \\
\text { the radical- } \\
\text { terrorist act } \\
\text { happened in } \\
\text { Surabaya. }\end{array}$ & 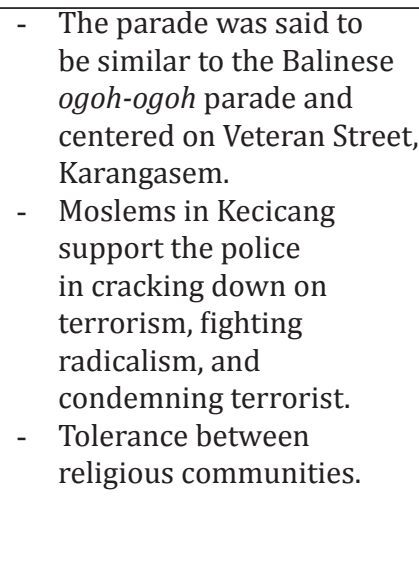 \\
\hline 5 & $\begin{array}{l}\text { "Karena Ini, } \\
\text { Radikalisme Tak } \\
\text { Bisa Berkembang } \\
\text { di Indonesia" } \\
\text { "Because of This, } \\
\text { Radicalism Can Not } \\
\text { Grow in Indonesia" } \\
\text { Balipost.com, } \\
\text { Sunday, May 20, } \\
2018\end{array}$ & $\begin{array}{l}\text { Radicalism } \\
\text { cannot growth } \\
\text { in Indonesia. }\end{array}$ & 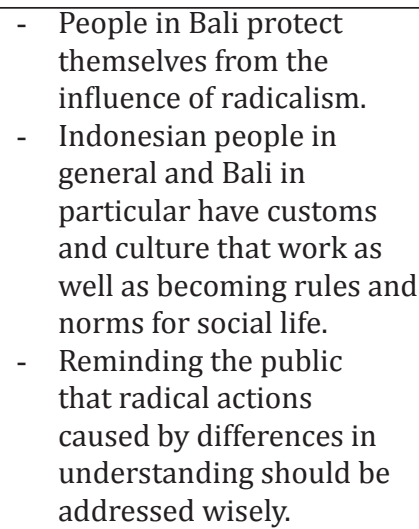 \\
\hline
\end{tabular}


Those issues that selected by the two media is using peace journalism perspective. Galtung indicator of peace journalism in this issue can be seen in Table 3 .

Table 3

News Issue in Galtung's Peace Journalism Perspective

\begin{tabular}{|c|c|c|c|}
\hline No. & News' Title & Issue/Aspect & $\begin{array}{c}\text { Galtung Peace } \\
\text { Journalism Indicator }\end{array}$ \\
\hline 1 & $\begin{array}{l}\text { "Antisipasi Teror Bom, } \\
\text { Polda Bali Sempat } \\
\text { Amankan Wanita } \\
\text { Bercadar" } \\
\text { "Anticipating Bom } \\
\text { Terror, Denpasar } \\
\text { Regional Police Secure a } \\
\text { Woman in Veil" } \\
\text { Beritabali.com, } \\
\text { Monday, May 14, } 2018\end{array}$ & $\begin{array}{l}\text { People worried } \\
\text { with a woman using } \\
\text { hijab and veil who } \\
\text { walk around Police } \\
\text { Stations. }\end{array}$ & $\begin{array}{l}\text { - } \\
\text { Emphaty, } \\
\text { understanding. } \\
\text { - } \text { Proactive, } \\
\text { prevention before } \\
\text { any violence/war } \\
\text { occurs. }\end{array}$ \\
\hline 2 & $\begin{array}{l}\text { "Remaja Denpasar } \\
\text { Berharap Tak Ada } \\
\text { Diskriminasi Karena } \\
\text { Berpakaian Mirip } \\
\text { Teroris" } \\
\text { "Denpasar Youth } \\
\text { Hopes There Is No } \\
\text { Discrimination for } \\
\text { Dressing Like Terrorists" } \\
\text { Beritabali.com, } \\
\text { Wednessday, May 23, } \\
2018\end{array}$ & $\begin{array}{l}\text { Young people in } \\
\text { Denpasar hoped } \\
\text { people should } \\
\text { not discriminate } \\
\text { person who wearing } \\
\text { the same dress } \\
\text { like executor in } \\
\text { Surabaya's bombing. }\end{array}$ & $\begin{array}{ll}\text { - } & \text { Peace }=\text { non- } \\
\text { violence }+ \\
\text { creativity. } \\
\text { - } \\
\text { Highlight peace } \\
\text { initiatives, also to } \\
\text { prevent more war. } \\
\text { - } \quad \text { Emphaty, } \\
\text { understanding. }\end{array}$ \\
\hline
\end{tabular}




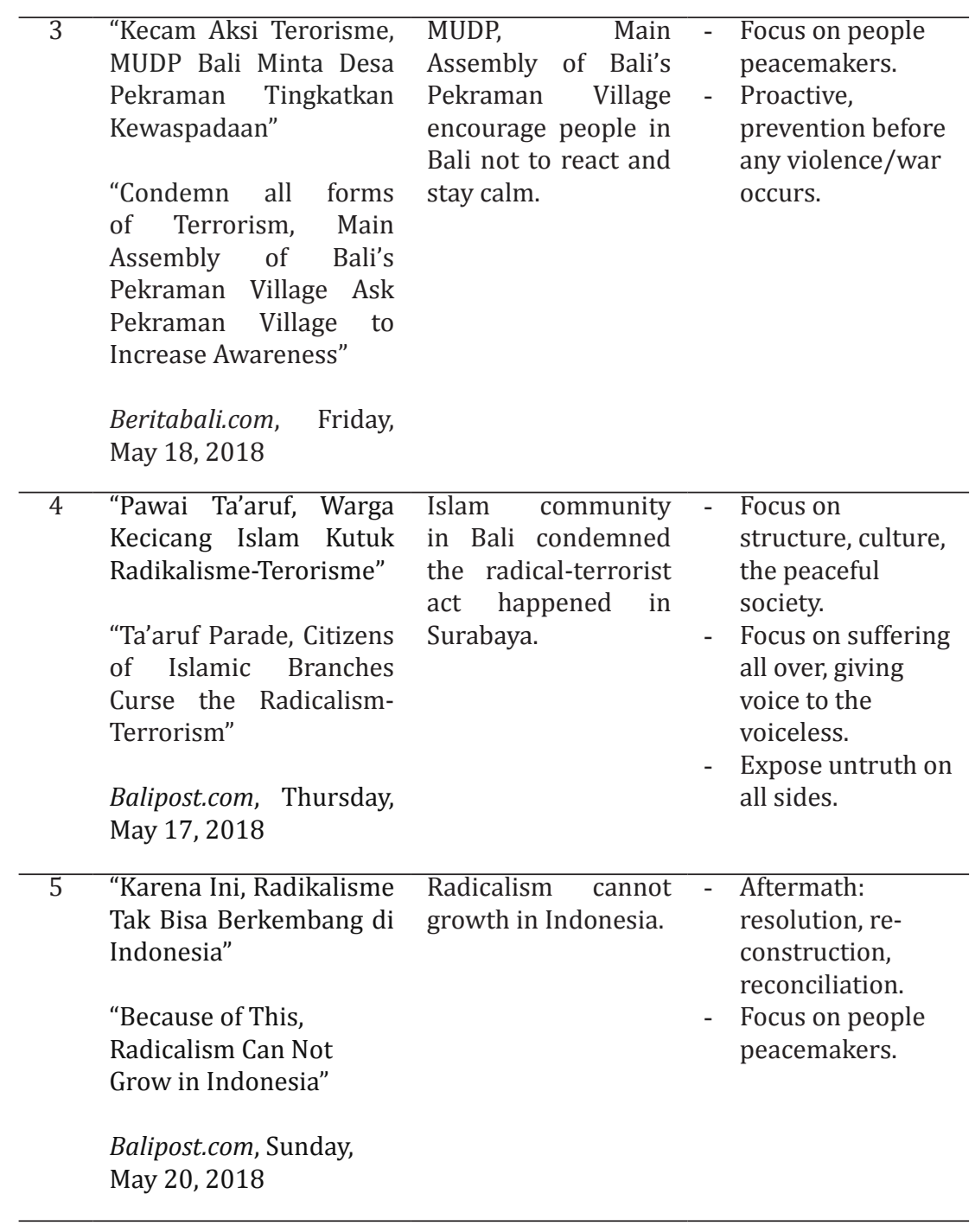

In table 3, researcher found out that news article in these two online media were using peace journalism. They advocate emphaty, understanding and prevention before any violence/war occurs in first article with title "Antisipasi Teror Bom, Polda Bali Sempat Amankan Wanita Bercadar". In second article, the media highlight peace initiatives, also to prevent more war and advocate emphaty for Muslim people in Bali. In third article, it focused on people peacemakers and proactive as prevention before any 
violence. The fourth article focused on structure, culture and a peaceful society, give voice to the voiceless and exposed untruth on all sides. The last article talked about the aftermath, resolution, focused on people peacemaker.

\section{Conclusion}

News framing related to Islam, Moslems, and radicalism issues in Balipost.com and Beritabali.com especially after the bombing in Surabaya is classified as promoting peace journalism. The issues raised by the two media are national issues, terrorism, and radical Islam, and highlighted both aspects by emphasized the importance of tolerance, not being discriminatory, by displaying photos that reflect tolerance and an official agreement that appealed the community to not being reactive or discriminatory. Another aspect that is highlighted was by presenting the culture of Moslems communities who are antithesis of radical Islamic Issues. This positive news framing has become one of the factors in maintaining good relations between Moslems and the Balinese people in general. 


\section{REFERENCES}

Abdulla, Rasha A. "Islam, Jihad, and Terrorism in Post 9/11 Arabic Discussion Board”, Journal of Computer-Mediated Communication 12, no. 1 (2007).

Abdullah, Anzar. "Gerakan Radikalisme dalam Islam: Perspektif Historis", ADDIN 10, no. 1 (2016).

"Antisipasi Teror Bom, Polda Bali Sempat Amankan Wanita Bercadar", Beritabali.com, May 14, 2018, https://www. beritabali.com/read/2018/05/14/201805140020/ Antisipasi-Teror-Bom-Polda-Bali-Sempat Amankan-WanitaBercadar.html, accessed August 13, 2019.

Campbell, C.P. Race, Myth, and The News. CA: Sage, 1995.

Entman, Robert. "Framing: toward Clarification of a Fractured Paradigm", Journal of Communication 43, no. 4 (1993).

Galtung, Johan. “Peace Journalism”, Media Asia 30, no. 3 (2003).

Hanitzsch, Thomas. "Journalists as Peacekeeping Force? Peace Journalism and Mass Communication Theory", Journalism Studies 5, no. 4 (2004).

"Karena Ini, Radikalisme Tak Bisa Berkembang di Indonesia", Balipost.com, May 17, 2018, http://www.balipost.com/ news/2018/05/20/45920/Karena-Ini,Radikalisme-TakBisa...html, accessed August 13, 2019.

"Kecam Aksi Terorisme, MUDP Bali Minta Desa Pekraman Tingkatkan Kewaspadaan", Beritabali.com, May 18, 2018, https://www. news.beritabali.com/read/2018/05/18/201805180009/ kecam-aksi-terorisme-mudp-bali-minta-desa-pekramantingkatkan-kewaspadaan, accessed August 13, 2019.

Krissa, Kathleen. "Pembingkaian Peristiwa Teror di Jalan Mh. Thamrin Jakarta pada Harian Kompas, Media Indonesia, Republika, dan Koran Sindo: Sebuah Analisis Framing", Bachelor Thesis, Universitas Multimedia Nusantara, 2016.

Lee, Seow Ting and Crispin C. Maslog, "War or Peace Journalism? Asian Newspaper Coverage of Conflicts", Journal of Communication 55, no. 2 (2005). 
McCombs, M., D.L. Shaw, and D. Weaver, Communication and Democracy: Exploring the Intellectual Frontiers in AgendaSetting Theory. Mahwah, NJ: Erlbaum, 1997.

Miller, Abraham H. Terrorism, the Media, and the Law. New York, NY: Transnational Publishers, 1982.

Nacos, B.L. Mass-Mediated Terrorism: the Central Role of the Media in Terrorism and Counter-Terrorism. New York, NY: Rowman and Littlefield, 2007.

"Pawai Ta'aruf, Warga Kecicang Bali Kecam Radikalisme-Terorisme", Balipost.com, May 17, 2018, http://www.balipost.com/ news/2018/05/17/45722/Pawai-Taaruf,Warga-KecicangIslam...html, accessed August 13, 2019.

Powell, Kimberly A. "Framing Islam: an Analysis of U.S. Media Coverage of Terrorism Since 9/11", Communication Studies 62, no. 1 (2011).

"RemajaDenpasarBerharapTakAdaDiskriminasiKarenaBerpakaian Mirip Teroris", Beritabali.com, May 23, 2018, https:// www.beritabali.com/read/2018/05/23/201805230007/ Remaja-Denpasar-Berharap-Tak-Ada-Diskriminasi-KarenaBerpakaian-Mirip-Teroris.html, accessed August 13, 2019.

Scheufele, D.A. "Framing as a Theory of Media Effects", Journal of Communication 49, no. 1 (1999).

Sukarno, Adam W. "Dilema Peliputan Terorisme dan Pergeseran Pola Framing Berita Terorisme di Media Massa”, Jurnal Ilmu Sosial dan Ilmu Politik 14, no. 3 (2011).

Tankard, J., L. Hendrickson, J. Silberman, K. Bliss, and S. Ghanem, "Media Frames: Approaches to Conceptualization and Measurement", Paper Presented at the Annual Conference of the Association for Education in Journalism and Mass Communication Boston, MA, 1991.

Tumber, Howard and Jerry Palmer, Media at War: the Iraq Crisis. Thousand Oaks, CA: Sage, 2004. 